\title{
Toward Decolonial Feminisms: Tracing the Lineages of Decolonial Thinking through Latin American/Latinx Feminist Philosophy
}

\author{
Emma D. Velez and Nancy Tuana
}

Departments of Philosophy and Women, Gender and Sexuality Studies, Penn State University, State College PA, 16801

Corresponding authors. Email eqv5073@psu.edu and ntuana@psu.edu

Survival can also be about keeping one's hopes alive; holding on to the projects that are projects insofar as they have yet to be realized. You might have to become willful to hold on when you are asked to let go; to let it go. Survival can thus be what we do for others, with others. We need each other to survive; we need to be part of each other's survival. (Ahmed 2017, 235)

"The decolonial feminist's task," María Lugones writes in her germinal essay "Toward a Decolonial Feminism," "begins by ... seeing the colonial difference, emphatically resisting [the] epistemological habit of erasing it" (Lugones 2010, 753). It is precisely this task that inspires us, the editors of and contributors to this special issue, "Toward Decolonial Feminisms: Tracing the Lineages of Decolonial Thinking through Latin American/ Latinx Feminist Philosophy."

A great deal of work, from myriad contexts and traditions, has articulated what Nelson Maldonado-Torres has called the "decolonial turn" (Maldonado-Torres 2011). Decolonial thinking emerging out of Latin American and Latinx contexts is of particular importance to the theoretical development of decolonial thinking and its uptake in mainstream philosophy. Engaged with, but seeking to differentiate their work from anticolonial and postcolonial theory, Latin American and Latinx decolonial philosophers emphasize the importance of the still lingering structures of colonialism in power, ontology, epistemology, and its entanglement with the imposed categorial logics of race and gender. This work has been at times influenced by, as well as developed parallel to and in conversation with, decolonial thinking from Indigenous philosophies as well as Africana and Caribbean philosophies. Indeed, we see our issue as aligned with rich traditions of decolonial thinking that emerge from heterogeneous sites, contexts, histories, and experiences of colonization and their subsequent impact on the workings of coloniality, such as the recent special issue of Hypatia, "Indigenizing and Decolonizing Feminist Philosophy" (35:1, Winter 2020).

However, as with much of philosophy, the "canon" of decolonial theory is comprised largely of and dominated by heterosexual cis-men. This is particularly evident in the centering of Aníbal Quijano, Walter Mignolo, Enrique Dussel, and Nelson Maldonado-Torres as primary articulators of the "decolonial turn," particularly in 
Latin American and Latinx contexts. Intervening into these intellectual genealogies, the aim of this special issue is to trace the specific contributions of Latin American and Latinx feminist philosophies to the development of the rich weave of decolonial philosophies as well as threads that intersect with other approaches to decolonial and/or postcolonial philosophies. In particular, this special issue features feminist scholarship that is informed by decolonial feminisms emerging from and in conversation with Latin American and Latinx feminisms.

Given the longstanding histories of colonization and rich traditions of decolonial thinking, particularly in the Americas, much work is required to further the philosophical articulation of decolonial feminisms as emergent methodological and philosophical orientations to anticolonial and feminist theory (and anticolonial feminist theory). We are energized by the insightful and generative contributions to decolonial feminist scholarship made by the contributors to this special issue. The international and interdisciplinary group of authors and essays gathered here are situated across borders and enact the richness and multiplicity of decolonial feminisms. We come from many places and "peopled grounds"-from across the US, Haiti, Colombia, and South Asia as well as from Native, first-generation Italian, and Chicanx communities (Lugones 2011, 83). Many of us write from diasporic positions within the United States and thus are bound up in ongoing colonial projects, such as US settler colonialism. Some of us write from our locations in the so-called "global South," contending with the sedimentation of the coloniality of power and the hegemonic status of academies and political elites in the "global North." All of us are committed to thinking and practicing what Lugones has termed "deep coalitions" that are not "epistemically shallow" but rather seek "a loving connection toward liberation" (Lugones 2006, 79).

We connect our attempts to enter into deep coalitions with Sara Ahmed's germinal work Living a Feminist Life. Here, Ahmed stresses the importance of "survival kits" for the feminist killjoy. We read the task of the decolonial feminist articulated by Lugones in solidarity with Ahmed's feminist killjoy. As such, decolonial feminists, too, require survival kits. As Ahmed explains, "We will accumulate different things, have our own stuff; we can peer into each other's kits and find in there someone else's feminist story" (Ahmed 2017, 236). Each essay in this special issue offers possibilities for constructing decolonial feminist survival kits, each from our own peopled ground.

Susana Matallana-Peláez's essay, "From Gender to Omeotlization: Toward a Decolonial Ontology," highlights the deep and intertwined relationship between Indigenous struggles against colonization and decolonial thought arising from Latin America. In so doing she places thinkers like María Lugones and Sylvia Rivera Cusicanqui into conversation while deliberately centering the decolonial resistance of indigenous peoples like the Zapatista and Aymara. Staging this dialogue enables Matallana-Peláez to place indigenous women's contributions to these decolonizing political movements at the heart of decolonial feminism and celebrates their insights regarding the deep imbrication of colonization and imposition of the hierarchical regimes of gender and race as crucial to what has come to be called the "coloniality of gender." Matallana-Peláez's deeply historicized examination of gender roles in Indigenous communities in Latin America spanning the colonial encounter grants deep insights into the injunction that Lugones terms the "decolonial feminist's task." Answering this call, the decolonial feminist survival kit assembled by Matallana-Peláez offers omeotlization as a response that privileges balance, movement, and equilibrium in the journey toward decolonized ways of being no longer beholden to "imperial reason" (2020). 
Picking up on this thread that seeks out the possibilities of responding to and taking up the decolonial feminist's task, we turn to Beaudelaine Pierre's "Thinking De $\Leftrightarrow$ coloniality through Haitian Indigenous Ecologies." Writing from and reckoning with her own diasporic Haitian identity, Pierre's survival kit opens another possibility for decolonizing subjectivities through the concept-practice of Lakou. Lakou, as Pierre describes it, is "that place from which she learns to press her fingers on her scars and wounds in order to sense better, to hear better, and to feel her body trembling with the landscape" (2020, p. 407). Offering us new concepts for our critical decolonial feminist vocabularies such as $\mathrm{de} \Leftrightarrow$ coloniality, what we read as an important reformulation of Lugones's oppressing $\Leftrightarrow$ resisting, Pierre emboldens and expands our decolonial feminist imaginaries so that we might begin "dreaming of things (not/yet/necessarily) seen and unseen, felt and unfelt, known and unknown" (2020, p. 396).

Lakou and omeotlization are two decolonial concept-practices that subvert the coloniality of philosophical knowledge-production. To these Diana María AcevedoZapata's essay, "Letter-Writing as a Decolonial Feminist Praxis for Philosophical Writing," adds alternative genres of writing, focusing on letter-writing, to our decolonial feminist survival kits. Acevedo-Zapata, writing from Colombia and the "political South," offers letter-writing as a way of subverting the epistemological norms of knowledgeproduction of the Western academy, often emanating from and situated in the "political North.” Acevedo-Zapata argues that letter-writing, in Spanish to other Spanish speakers, expands practices of doing philosophy and ought to be considered a form of decolonial feminist praxis, a way of doing decolonial feminist philosophy. As she explains, "a decolonial feminist praxis starts by recognizing there is necessarily a place of enunciation for authors in philosophy, and that it cannot be neutral, objective, or universal" (2020, p. 413). By emphasizing the particularity of the subjectivities of those exchanging letters, letter-writing as genre subverts relations ordered by coloniality.

As we compile our decolonial feminist survival kits, it is imperative to remember those who have come before us and the heirlooms they leave behind. We find this lesson at the heart of Shara Cherniak and Ashli Walker's essay, "The 'New': A Colonization of Non-Modern Scholars and Knowledges." Cherniak and Walker urge us to carefully reflect on how thoroughly the coloniality of knowledge has saturated Western feminist lexicons, particularly those that appeal to "the new" as a way of making sense of their knowledge-making projects. As they argue, "The notion that these philosophies enact 'unprecedented things' privileges the colonizing philosophies of the Euro-Western 'new' and have no interest in substantially engaging the aforementioned historically disenfranchised philosophies in their conversations, and thus persisting the new/old dichotomy!" (2020, p. 432).

Remembering is necessarily bound up with forgetting, as Ege Islekel reminds us in her essay, "Traveling the Soil of Worlds: Haunted Forgettings and Opaque Memories." Forgetting, on Islekel's account, is understood as a form of opacity. Utilizing Glissant's understanding of opacity and the materiality of silt as that which is so granular and fine that it is suspended in fluids, yet, when it accumulates, can also form ground, Islekel contends, "One travels between worlds through silts and alluviums deposited by other world-travelers, and one's previous experiences: it shocks the system, yes, but rather than cutting the membrane, these create sediments that become the soil for traveling between worlds" (2020, p. 451). As such, forgetting is not something that is merely oppressive but an important and resistant asset in the survival kit of the decolonial feminist. 
The decolonial feminist survival kit offered by Brooklyn Leo in their article, "The Colonial/Modern [Cis] Gender System and Trans World Traveling," importantly attends to the lives of trans, two-spirit, and gender-nonconforming people of color. Engaging Lugones's theorization of the coloniality of gender, Leo demonstrates that cisgender violence and transphobia are at the heart of what Lugones has termed the colonial/modern gender system. We find this intervention to be profoundly important for Lugones's decolonial feminist account of the co-constitution of the categorial logics of race and gender through the coloniality of gender. As Leo contends, through their bodies and lived experience that refuses the terms of the coloniality of gender, Trans of Color and Two-Spirit people inhabit worlds and decolonial imaginaries that are in excess of the modern/colonial gender system. Offering world-traveling and cocooning as lifegiving tools, Leo writes, "Through world-traveling, the material bodies of Trans of Color folks creatively cocoon new worlds of sense where gender is anticolonial” (2020, p. 471).

World-traveling is also central to the decolonial feminist survival kit compiled by Melanie Bowman in her essay "Privileged Ignorance, 'World'-Traveling, and Epistemic Tourism." Addressing those who occupy privileged positions in relation to systems of oppression interested in coalition-building against these systems, Bowman places Lugones's theorization of world-traveling in conversation with Jose Medina's concept of epistemic friction in order to combat what she calls "privileged ignorance." As Bowman explains, "Privileged people wishing to be helpful allies must interrogate whether we are as ignorant of systems of oppression as we claim to be, since false claims of ignorance enable us to disavow responsibility for oppression, all the while idly wishing it would stop" (2020, p. 485). Rather than advising aspiring allies to understand "what it's like" to live as someone subject to systems of oppression, which Bowman terms "epistemic tourism," Bowman instead recommends dwelling in one's unknowing in order to prompt self-reflective interrogation of one's own ignorance of oppressions resulting from colonization or racism.

Enacting the self-reflective interrogation recommended by Bowman, Paula Martins, Silva Fernanda, and Alexandre Carrieri theorize from their experience of leading a workshop aimed at the empowerment of quilombola women in "rural" Brazil in their essay, "For the Decolonization of the Researcher's Self: An Encounter with Brazilian Quilombola Women and Reflections about the Coloniality of Rurality." Considering their positions as researchers trained in the Western tradition of universal knowledge that Santiago Castro Gomez terms the "hubris of the zero-point" and teaching the quilombola women as outsiders from an urban center, Martins, Fernanda, and Carrieri trouble their own complicity with the coloniality of power, knowledge, and gender. As they recount, "We idealized quilombola rurality, imbuing it with premodern attributes as if it were still frozen in the old days. ... However, being close to the quilombola women was a demystifying experience that led us to question our roles as researchers and urban women, so as to approach other women without overwhelming them" (2020, p. 496). The authors, through their own experiences, urge those of us engaged in academic knowledge-production to take seriously the imperative of decolonizing the researcher's self. This revolutionary task "requires that we decolonize our scientific and writing practices so that rationality ceases to be universalized and becomes plural, diversified, and inclusive of the knowledge forms produced by others" (2020, p. 506).

Resonating with Bowman's attention to epistemic practices that perpetuate forms of ignorance that aid and abet colonial logics, K. Bailey Thomas's essay, "Intersectionality and Epistemic Erasure: A Caution to Decolonial Feminism," focuses on forms of epistemic erasure that are detrimental to the coalitional project that lies at the heart of 
decolonial feminist endeavors. Contending with Lugones's critiques of Kimberlé Crenshaw's articulation of intersectionality, Thomas attends to the resonances and tensions between the two thinkers' accounts of multiplicity and oppression. In particular, Thomas draws attention to a dangerous from of epistemic erasure that underlies Lugones's critiques of Crenshaw that risk appealing to the very colonial logics she seeks to dismantle. As they explain, "I see Lugones making a semantic argument here regarding the difference between 'intersectionality' and 'fusion,' but I would argue that we should be concerned with the function of intersectionality rather than wordplay. In terms of its operation and sentiment regarding oppressive logics and a call for resistance, fusion and intersectionality seem to operate simultaneously" (2020, pp. 515-516). Thomas's decolonial feminist survival kit is deeply informed by the work of Black feminists. Building on this rich tradition, Thomas issues a call not just for critique of the structures of oppression but an injunction to combine the insights of decolonial feminism and intersectionality in order to "develop an imaginative resistance within our epistemology to create new structures” (2020, p. 518).

Building from Thomas's injunction but shifting to a different register, Ashley Bohrer's essay, “Toward a Decolonial Feminist Anticapitalism: María Lugones, Sylvia Wynter, and Sayak Valencia," takes up the rich tradition of anticapitalist critique developed within decolonial feminism. Placing the work of Lugones, Wynter, and Valencia into conversation with one another, Bohrer tracks the crucial insights of these thinkers regarding the deep imbrication of capitalism, colonialism, racism, and heterosexism. Considering their insights together, Bohrer contends, yields an emphasis on a polycentric and multifaceted methodological approach to theorizing capitalism that "attends to differences across multiple geographies" (2020, p. 537). As she argues, "Rethinking what capitalism is in line with the insights of Lugones, Wynter, and Valencia reveals it to be a deeper and more complex system than is often supposed; this in turn requires that resistance too becomes more capacious to rise to the challenge" (2020, p. 537). The gathering convened in Bohrer's decolonial feminist survival kit thus emphasizes the importance of multiplicity and difference in both our decolonial feminist theory and resistant praxis.

We close this special issue with Kiran Asher and Priti Ramamurthy's important musing, "Rethinking Decolonial and Postcolonial Knowledges beyond Regions to Imagine Transnational Solidarity." Emphasizing the importance of transnational solidarity and coalition-building, the authors urge more careful and nuanced conversations among anticolonial feminists, particularly self-identifying postcolonial and decolonial feminists. To illustrate the need for such continued dialogues, the authors recount what we might call a desencuentro at the 2016 meeting of the National Women's Studies Association (NWSA). ${ }^{2}$ Placed on a panel aimed at staging a conversation between postcolonial and decolonial feminists as representatives of "postcolonial feminists," the authors explain how a continued appeal to "region" stifled the possibilities of formation of transnational solidarities. Rather than attending to the complexities of the affinities and tensions of the anticolonial feminists gathered in the space, the authors tell of a stifling and binaristic (mis)representation of the postcolonial-as-South Asian and decolonial-as-Latin American. "Such binaries," the authors argue, "do little to explain the complex relations by which colonial differences endure and bind us" (2020, p. 545).

We take this Musing as a caution to those committed to feminist critiques of the violent and oppressive legacies and histories of colonialism and coloniality. Indeed, as Laura Perez has told us, "it matters that we walk our brave decolonizing talks" (Pérez 2010, 123). To avoid becoming mired in what Mariana Ortega has called 
"decolonial woes" (Ortega 2017), wherein we repeat and perform the very colonial logics we seek to critique and dismantle, decolonial feminists must remain vigilant to tendencies to reduce complexities and appeals to purity that deploy categorial logics. We find many instructive strategies and tactics in the decolonial feminist survival kits assembled here.

We conclude our introduction by offering our sincere thanks to our editorial team at Hypatia, to the dedicated anonymous reviewers whose gracious comments and steadfast advice enhanced the work presented here, and especially to our authors for sharing their wisdom and their visions. Producing this special issue required complex communication, deep coalition, and the efforts of many decolonial imaginaries.

\section{Notes}

1 We place "global South" in scare quotes here to denote that this term is problematic and deeply tied to the colonial imaginary and legacies of colonization that this issue sets out to critique and homogenizes the deep global diversity of peoples in these regions of the world.

2 An encuentro, loosely translated from Spanish, is a meeting or encounter. Thus, a desencuentro is a failed meeting and is often translated as a disagreement. As Joshua Price and Maria Lugones recount their own experience of a desencuentro in their article "Encuentros and Desencuentros: Reflections on a LATCRIT Colloquium in Latin America," "[W]e looked at the discussion in Buenos Aires as opening new venues, new possibilities of communication on the issues... . But ... the discussion did not meet this conjunction of oppressions head on. It rather missed it: un desencuentro, a missing of what we think of as a necessary conversation among subaltern peoples" (Price and Lugones 2004, 743).

\section{References}

Acevedo-Zapata, Diana María. 2020. Letter-Writing as a Decolonial Feminist Praxis for Philosophical Writing. Hypatia 35 (3): 410-423.

Ahmed, Sara. 2017. Living a feminist life. Durham, N.C.: Duke University Press.

Asher, Kiran, and Priti Ramamurthy. 2020. Rethinking Decolonial and Postcolonial Knowledges beyond Regions to Imagine Transnational Solidarity. Hypatia 35 (3): 542-547.

Bohrer, Ashley J. 2020. Toward a Decolonial Feminist Anticapitalism: María Lugones, Sylvia Wynter, and Sayak Valencia. Hypatia 35 (3): 524-541.

Bowman, Melanie. 2020. Privileged Ignorance, 'World'-Traveling, and Epistemic Tourism. Hypatia 35 (3): 475-489.

Cherniak, Shara, and Ashli Moore Walker. 2020. The 'New:' A Colonization of Non-Modern Scholars and Knowledges. Hypatia 35 (3): 424-438.

Islekel, Ege Selin. 2020. Traveling the Soil of Worlds: Haunted Forgettings and Opaque Memories. Hypatia 35 (3):, 439-453.

Leo, Brooklyn. 2020. The Colonial/Modern [Cis]Gender System and Trans World Traveling. Hypatia 35 (3): 454-474.

Lugones, María. 2006. On complex communication. Hypatia 21 (3): 75-85.

Lugones, María. 2010. Toward a decolonial feminism. Hypatia 25 (4): 742-59.

Lugones, María. 2011. Methodological notes toward a decolonial feminism. In Decolonial epistemologies: Latina/o theology and philosophy, ed. Ada María Isasi-Díaz and Eduardo Mendieta. New York: Fordham University Press.

Matallana-Peláez, Susana E. 2020. From Gender to Omeotlization: Toward a Decolonial Ontology. Hypatia 35 (3): 373-392.

Maldonado-Torres, Nelson. 2011. Thinking through the decolonial turn: Post-continental interventions in theory, philosophy, and critique-An introduction. Transmodernity 1 (2): 1-15.

Ortega, Mariana. 2017. Decolonial woes and practices of un-knowing. Journal of Speculative Philosophy 31 (3): 504-16. 
Pérez, Laura E. 2010. Enrique Dussel's etica de la liberacio'n, U.S. Women of color decolonizing practices, and coalitionary politics amidst difference. Qui Parle: Critical Humanities and Social Science 18 (2): 121-46.

Pierre, Beaudelaine. 2020. Thinking De $<=>$ coloniality through Haitian Indigenous Ecologies. Hypatia 35 (3): 393-409.

Price, Joshua, and María Lugones. 2004. Encuentros and desencuentros: Reflections on a LATCRIT colloquium in Latin America. Florida Journal of International Law 16 (1): 743-51.

Silva, Fernanda, Paula Martins, and Alexandre Carrieri. 2020. For the Decolonization of the Researcher's Self: An Encounter with Brazilian Quilombola Women and Reflections about the Coloniality of Rurality. Hypatia 35 (3): 490-508.

Thomas, K. Bailey. 2020. Intersectionality and Epistemic Erasure: A Caution to Decolonial Feminism. Hypatia 35 (3): 509-523.

Emma D. Velez is an Andrew W. Mellon Foundation dissertation fellow and $\mathrm{PhD}$ candidate in Philosophy and Women's, Gender, and Sexuality Studies at The Pennsylvania State University. In fall 2020, she will start her position as an Assistant Professor of Gender and Women's Studies at the University of Illinois, Urbana-Champaign. Engaging the work of US Latinx feminists, her research examines the contributions that decolonial feminisms make to rethinking questions of identity, epistemology, and ethicopolitical strategies for decolonization. eqv5073@psu.edu

Nancy Tuana is the DuPont/Class of 1949 Professor of Philosophy and Women's, Gender, Sexuality Studies at Penn State and is the founding director of the Penn State Rock Ethics Institute. Her most recent book, Beyond Philosophy: Nietzsche, Foucault, Anzaldúa, co-authored with Charles Scott (Indiana University Press, 2020), occasions practices of attunement to unspeakable dimensions of experience that are a hitherto seldom noticed dimension of liberatory thought. Her scholarly work includes books and articles in feminist history of philosophy, epistemologies of ignorance, and feminist science studies, with particular expertise in intersectional approaches to environmental issues and coupled ethical-epistemic issues in climate change science. She is series editor for ReReading the Canon with Penn State Press and has guest edited several special issues of Critical Philosophy of Race and Hypatia. ntuana@psu.edu

Cite this article: Velez ED, Tuana N (2020). Toward Decolonial Feminisms: Tracing the Lineages of Decolonial Thinking through Latin American/Latinx Feminist Philosophy. Hypatia 35, 366-372. https:// doi.org/10.1017/hyp.2020.26 